\title{
APPLICATION OF THE STOPP/ START CRITERIA IN THE SURVEY OF MEDICATION USE IN ELDERLY PATIENTS WITH RENAL FAILURE
}

\author{
Aleksandra CATIĆ-ĐORĐEVIĆ ${ }^{1 \bowtie}$, Nikola STEFANOVIĆ ${ }^{1}$, Ivana STOŠIĆ ${ }^{2}$, \\ Ivana DAMNJANOVIĆ ${ }^{1}$, Ivana MILANOVIĆ ${ }^{1}$, Novica BOJANIĆ ${ }^{1}$, \\ Radmila VELIČKOVIĆ-RADOVANOVIĆ1,3 \\ ${ }^{1}$ Faculty of Medicine, University of Nis, Nis, Serbia \\ ${ }^{2}$ Institute for Treatment and Rehabilitation „Niska Banja“, Nis, Serbia \\ ${ }^{3}$ Clinic of Nephrology, Clinical Centre Nis, Nis, Serbia
}

Received 25 Oct 2019, Accepted 19 Nov 2019

https://doi.org/10.31688/ABMU.2019.54.4.10

\begin{abstract}
Introduction. The risk of inappropriate prescribing and inadequate drug use in the elderly population is growing with ageing associated physiological changes and polypharmacy due to increased number of chronic diseases. In order to optimize the therapy, numerous criteria have been developed which can help pharmacists and physicians to implement rational pharmacotherapy.

The objectives of the study were to survey the practice of medication use in patients older than 65 years with different stages of renal failure and to identify potentially inappropriate prescribing, as well as to justify the role of pharmacists in pharmacotherapy optimization.
\end{abstract}

Material and methods. This retrospective study included 100 patients with average age of $72.30 \pm 5.00$ years. Demographic, clinical and pharmacotherapy data were collected from hospital discharge summary after one day hospital examination at the Clinic of Nephrology of Clinical Center Niš, Serbia. Potentially inadequate drugs were identified by STOPP

\section{Résumé}

Application des critères Stopp / Start dans une étude sur l'emploi de la médication chez les patients âgés souffrant d'insuffisance rénale

Introduction. Les changements physiologiques, l'augmentation du nombre de maladies chroniques et la polypharmacie augmentent le risque de prescription inappropriée et d'utilisation inadéquate de médicaments chez les personnes âgées. Afin d'optimiser le traitement, de nombreux critères ont été développés.

Le but de la recherche. L'étude avait pour objectif de passer en revue les médicaments chez les patients âgés de plus de 65 ans avec insuffisance rénale dans différents stades et d'identifier une prescription potentiellement inappropriée. Les résultats étaient liés au rôle des pharmaciens dans l'optimisation de la pharmacothérapie.

Méthodes. Cette étude rétrospective a porté sur 100 patients âgés en moyenne de 72,30 $\pm 5,00$ ans. Les données démographiques, cliniques et pharmacothérapeutiques ont été collectées sur la base du document 
criteria (Screening Tool of Older Persons' Prescriptions), while START criteria (Screening Tool to Alert doctors to Right Treatment) pointed out the lack of potentially helpful drugs in therapy.

Results. 63 STOPP and 60 START criteria were identified. The most common STOPP criteria were the use of benzodiazepines (14\%) and duplication of therapy (11\%). The greatest influence on the occurrence of STOPP criteria was the total number of medications in therapy. START criteria identified the lack of statins in therapy in $19 \%$ of patients with cardiovascular disease and in 13\% with diabetes mellitus type 2 . The occurrence of START criteria was mostly influenced by the number of comorbidities.

Conclusions. The presence of potentially inadequate prescribed and the lack of potentially useful drugs in the complex pharmacotherapy of elderly patients is the reason for including pharmacists in a team which creates optimal pharmacotherapy for elderly.

Keywords: geriatric population, STOPP/START criteria, rational pharmacotherapy, pharmacists.

\section{Abbreviations:}

STOPP = Screening Tool of Older Persons' Prescriptions

START $=$ Screening Tool to Alert doctors to Right

Treatment

$\mathrm{WHO}=$ World Health Organization

IP = Inappropriate Prescribing

PIP = Potentially Inappropriate Prescribing

$\mathrm{PIMs}=$ Potentially Inappropriate Medications

BMI $=$ Body Mass Index

ACC $/ \mathrm{AHA}=$ American College of Cardiology/

American Heart Association

\section{INTRODUCTION}

The geriatric population is considered to be over 65 years old, accounting for about 13\% of the world's population ${ }^{1}$. The World Health Organization (WHO) distinguishes the following categories within the geriatric population ${ }^{1,2}$ :

- elderly people (60-74 years);

- old people (75-90 years) and;

- very old people (over 90 years).

Chronic health conditions are more prevalent among older adults, as well as multiple medications use. Polypharmacy (use of five or more medications daily) may increase the risk of inappropriate medications use, the development of adverse drug reactions, the appearance of drug-drug and drug-disease interactions. The risk of adverse drug reactions is also higher with age-related changes in pharmacokinetics de sortie de l'hôpital après l'examen d'un jour à la Clinique de néphrologie du Centre clinique de Niš. Les médicaments potentiellement inadéquats ont été identifiés par les critères STOPP (Screening Tool of Older Persons' Prescriptions), tandis que les critères START (Screening Tool to Alert doctors to Right Treatment) soulignaient l'omission de prescriptions considérées comme appropriées dans la thérapie

Résultats. 63 critères STOPP et 60 critères START ont été identifiés. Les critères STOPP les plus courants étaient l'utilisation de benzodiazépines (14\%) et la duplication de médicaments (11\%). La plus grande influence sur l'occurrence des critères STOPP était le nombre de médicaments en thérapie. Les critères START ont mis en évidence un déficit thérapeutique en statines chez $19 \%$ des patients atteints de maladie cardiovasculaire et chez 13\% des patients atteints de diabète de type 2. La survenue des critères START était principalement affectée par le nombre de comorbidités.

Conclusions. La présence de la prescription médicamenteuse potentiellement inappropriée et le manque de médicaments potentiellement utiles dans la pharmacothérapie complexe des personnes âgées justifient l'inclusion de pharmaciens en équipe qui crée une pharmacothérapie optimale pour les personnes âgées.

Mots-clés: population gériatrique, critères STOPP/ START, pharmacothérapie rationnelle, pharmaciens.

and pharmacodynamics. Older adults have decreased function of liver and kidneys, reduced cognition, vision, hearing and mobility. Almost, a third of the total medications are consumed by older adults ${ }^{2}$. The pharmacists can help physicians in rationalization of pharmacotherapy by selecting the medication and setting the optimal dosage regimen. The pharmacists should be included in the healthcare team in order to optimize health outcomes.

Polypharmacy and inappropriate prescribing (IP) are risk factors for the occurrence of adverse effects that may be the cause of unfavorable clinical outcomes $^{3}$. Polypharmacy is present in a large number of patients. It increases the risk of developing adverse reactions such as weight loss, falls, functional and cognitive impairment, leads to hospitalization, but is not associated with a greater survival of patients ${ }^{4}$. Inappropriate prescribing is present when the risk 
associated with use of prescribed drugs outweighs the potential benefit ${ }^{5}$. The term Potentially Inappropriate Prescribing (PIP) includes not only misprescribing, but also overprescribing and underprescribing ${ }^{4}$.

Polypharmacy is closely linked to the risk of PIP and increases linearly with the number of drugs used. The increase in the number of medications carries a risk of drug use without clinical indications, can reduce dependence of patients, but also can increase treatment costs ${ }^{6}$.

In order to identify potentially inadequate prescribing and reduce the risk of adverse drug reaction, different criteria have been developed to help pharmacists when they assess the medication. Potentially inadequate medicines in the treatment of elderly adults which can change the benefit-risk ratio and increase the risk of adverse drug reactions, due to aging-induced changes, are identified by STOPP criteria (Screening Tool of Older Persons' Prescriptions). Also, criteria for drugs which could be useful in certain indications in older patients have been established (Screening Tool to Alert doctors to Right Treatment - START). The criteria were developed in Ireland using „Delphi“ consensus technique by $18 \mathrm{ex}$ perts in the field of geriatric pharmacotherapy from academic centers of the Great Britain and Ireland ${ }^{5}$. STOPP/START criteria have some advantages over the frequently used Beers criteria ${ }^{1}$ because they are conceived according to physiological systems and related to drug classes that facilitate their application ${ }^{5}$. Also, special attention has been paid to the use of narcotic analgesics, drugs that can adversely affect people prone to falls, and the occurrence of therapy duplication (two drugs from the same pharmacotherapy group) ${ }^{7}$.

\section{THE OBJECTIVE OF THE STUDY}

The main objective of the study was to assess medication of geriatric patients with different stages of renal failure using STOPP and START criteria, in order to identify potential inappropriate prescribing. The second objective was to justify the role of pharmacist in the prescription of the rational and optimal pharmacotherapy in elderly patients.

\footnotetext{
${ }^{1}$ In 1991 Mark Beers and colleagues created a list of drugs that were considered to be potentially inappropriate for use in older people. The disadvantages of this list were limited applicability outside of the United States, failure to solve problems such as drug-drug and drug-disease interaction, failure to include criteria related to underprescribing and to adaptation of the body. Because of that, they have been changed many times until now.
}

\section{Material AND MEthods}

A retrospective study, which included 104 patients, was carried out at Clinic of Nephrology of Clinical Center Nis, Serbia, from March to May 2018. Demographic, clinical and pharmacotherapy data were collected on the basis of hospital discharge summary after one day hospital examination. The patients were older than 65 years, with renal failure and comorbidities (median 6.0). Four patients were excluded from the study due to incomplete therapy data. Analyzed data included: patients' medical history, clinical and diagnostic findings, conclusions on the patient's medical condition, prescribed therapy at discharge and additional advices. The most important data for evaluation of medication given to patients were gender, age, body mass index (BMI), potassium level, number of drugs and number of comorbidities per patient. Identification of potentially inappropriate drugs was performed using the STOPP/START criteria.

STOPP criteria include 65 clinically relevant statements that help healthcare providers identify Potentially Inappropriate Medications (PIMs). Each criterion was accompanied by a concise explanation of why the practice of prescribing is potentially inappropriate. START criteria comprise 22 statements indicating Potential Prescribing Omissions (PPOs) ${ }^{5,8}$.

The obtained data were statistically processed by software SPSS 16 and given in tabular form.

\section{Results}

The demographic data of the homogenous group of patients are shown in Table 1. The results are expressed as the mean values with standard deviation $(\mathrm{X} \pm \mathrm{SD})$ and interquartile difference. The average age of the patients was $72.30 \pm 5.00$ years. The study group comprised $56 \%$ males and $44 \%$ females. The average number of medications was $6.20 \pm 2.79$ per patient. The average glomerular filtration rate showed a reduced renal function in all subjects $(63.64 \pm 26.37 \mathrm{ml}$ / $\min / 1.73 \mathrm{~m}^{2}$ ) (Table 1$)$.

The results of the identified PIPs in accordance with the applied STOPP/START criteria are shown in Table 2.

In total, 63 STOPP and 60 START criteria were identified. Inappropriately prescribed drugs were identified in $44 \%$, while the absence of potentially useful drugs was recorded in $36 \%$ of patients. Presented PIPs are identified taking into account the number of comorbidities in patient and the number of drugs in the therapy. A statistically significant difference in the number of PIPs among the patients 
Table 1. Characteristics of the examined group

\begin{tabular}{|c|c|}
\hline Characteristics & Examined group $(\mathrm{N}=100)$ \\
\hline \multicolumn{2}{|l|}{ Gender (\%) } \\
\hline Male & $56 \%$ \\
\hline Female & $44 \%$ \\
\hline \multicolumn{2}{|l|}{ Age (years) } \\
\hline $\mathrm{X} \pm \mathrm{SD}$ & $72.30 \pm 5.00$ \\
\hline Median (IQR) & $71.00(8.00)$ \\
\hline \multicolumn{2}{|l|}{ Age (N\%) } \\
\hline$<75$ years & $68 \%$ \\
\hline$\geq 75$ years & $32 \%$ \\
\hline \multicolumn{2}{|l|}{$\operatorname{BMI}\left(\mathrm{kg} / \mathrm{m}^{2}\right)$} \\
\hline $\mathrm{X} \pm \mathrm{SD}$ & $29.14 \pm 4.92$ \\
\hline Median (IQR) & $29.26(6.56)$ \\
\hline \multicolumn{2}{|l|}{$\mathrm{K}(\mathrm{mmol} / \mathrm{L})$} \\
\hline $\mathrm{X} \pm \mathrm{SD}$ & $4.62 \pm 0.52$ \\
\hline Median (IQR) & $4.60(0.65)$ \\
\hline \multicolumn{2}{|l|}{$\mathrm{eGFR}\left(\mathrm{mL} / \mathrm{min} / 1.73 \mathrm{~m}^{2}\right)$} \\
\hline $\mathrm{X} \pm \mathrm{SD}$ & $63.64 \pm 26.37$ \\
\hline Median (IQR) & $60.75(35.51)$ \\
\hline \multicolumn{2}{|l|}{ Number of drugs/patient } \\
\hline $\mathrm{X} \pm \mathrm{SD}$ & $7.52 \pm 3.12$ \\
\hline Median (IQR) & $8.00(4.00)$ \\
\hline \multicolumn{2}{|l|}{ Number of drugs (\%) } \\
\hline$\leq 5$ & $29 \%$ \\
\hline$>5, \leq 10$ & $57 \%$ \\
\hline$>10$ & $14 \%$ \\
\hline \multicolumn{2}{|l|}{ Number of comorbidities/ } \\
\hline $\begin{array}{l}\text { patient } \\
\mathrm{X}+\mathrm{SD}\end{array}$ & $6.20 \pm 2.79$ \\
\hline $\begin{array}{l}\text { X } \pm \text { SD } \\
\text { Median (IQR) }\end{array}$ & $6.00(4.00)$ \\
\hline
\end{tabular}

$\mathrm{X} \pm \mathrm{SD}$ - mean value and standard deviation IQR - interquartile difference

$\mathrm{K}$ - potassium level

eGFR - estimated glomerular filtration rate

from two categories of elderly $65-74$ years old and older than 75 years is not found using $\chi^{2}$ test.

The most commonly identified STOPP/START criteria are shown in Table 3.

The use of benzodiazepines was identified as the main reason for use of STOPP criteria. Therapeutic duplication was recorded in high percentage of cases too. The reasons for use of STOPP criteria were also the use of aspirin in patients without a history of coronary, cerebral or peripheral vascular symptoms or diseases and long-term use of digoxin (125 mg/daily) in patients with decreased renal function.

The most frequently identified START criterion was the absence of statins in patients with a documented history of coronary, cerebral or peripheral vascular diseases who were independent in performing basic activities of daily living $(31.70 \%$ of total number of used START criteria). The use of START criteria related to the endocrine system prescribed pharmacotherapy was also recorded: as use of statins
Table 2. STOPP and START criteria.

\begin{tabular}{cc}
\hline Characteristics & Examined group $(\mathrm{N}=100)$ \\
\hline STOPP criteria (YES/NO) & $44 / 56$ \\
\hline Total STOPP & 63 \\
\hline START criteria (YES/NO) & $36 / 64$ \\
\hline Total START & 60 \\
\hline STOPP criteria per drug & $0.20 \pm 0.15$ \\
\hline STOPP criteria per patient & 1.43 \\
\hline $\begin{array}{c}\text { STOPP criteria per comor- } \\
\text { bidity }\end{array}$ & $0.31 \pm 0.27$ \\
\hline START criteria per patient & 1.66 \\
\hline START criteria per drug & $0.19 \pm 0.08$ \\
\hline $\begin{array}{c}\text { START criteria per comor- } \\
\text { bidity }\end{array}$ & $0.23 \pm 0.10$ \\
\hline
\end{tabular}

in diabetes mellitus type 2 with presence of major cardiovascular risk factors and use of metformin in diabetes mellitus type 2 with or without the presence of metabolic syndrome.

The results which show the impact of individual factors on the occurrence of PIP in accordance with the STOPP/START criteria are presented in Tables 4 and 5.

Table 4 shows the data obtained by logistic regression related to the STOPP criteria. The most significant influence on the occurrence of STOPP criteria has the number of drugs, while the age of patients, gender and the number of comorbidities have not shown significant association with the occurrence of PIP.

The influence of patient's gender, age, number of comorbidities and drugs on the occurrence of START criteria is shown in Table 5.

The number of comorbidities is found by logistic regression as the most significant factor which influences on the occurrence of START criteria.

\section{Discussion}

Rational and appropriate drug prescribing for geriatric population is of great importance ${ }^{9}$. It contributes to reduction of drug adverse effects, enables optimal health outcomes and may reduce the costs of additional treatment ${ }^{10}$. Potentially inadequate therapy in the elderly patients is easier to identify by applying the criteria ${ }^{11}$. In previous retrospective researches was registered the presence of polypharmacy in the elderly patients treatment, as well as the connection between polypharmacy and the occurrence of PIP $\mathrm{P}^{12,13}$. Also, the role of pharmacists in PIP recognition by using criteria was justified. We have also registered the presence of polypharmacy and its association with 
Table 3. The most commonly identified STOPP/START criteria.

\begin{tabular}{|c|c|c|c|c|c|}
\hline \multicolumn{3}{|c|}{ The most commonly identified STOPP criteria } & \multicolumn{3}{|c|}{ The most commonly identified START criteria } \\
\hline Criteria & $\begin{array}{c}\% \\
\text { patients }\end{array}$ & $\begin{array}{l}\% \text { of participation } \\
\text { in relation to total } \\
\text { number of STOPP }\end{array}$ & Criteria & $\begin{array}{c}\% \\
\text { patients }\end{array}$ & $\begin{array}{l}\text { \% of participation } \\
\text { in relation to total } \\
\text { number of START }\end{array}$ \\
\hline Benzodiazepines & 14 & 22.2 & $\begin{array}{l}\text { Statin therapy with a } \\
\text { documented history } \\
\text { of coronary, cerebral } \\
\text { or peripheral vascular } \\
\text { disease, where the patient's } \\
\text { functional status remains } \\
\text { independent for activities } \\
\text { of daily living and life } \\
\text { expectancy is greater than } \\
5 \text { years }\end{array}$ & 19 & 31.70 \\
\hline $\begin{array}{l}\text { Any duplicate drug } \\
\text { class prescription e.g. } \\
\text { two concurrent opiates, } \\
\text { NSAID's SSRI's, loop } \\
\text { diuretics, ACE inhibitors }\end{array}$ & 11 & 17 & $\begin{array}{l}\text { Statin therapy in Diabetes } \\
\text { mellitus if co-existing } \\
\text { major cardiovascular risk } \\
\text { factors present }\end{array}$ & 13 & 21.70 \\
\hline $\begin{array}{c}\text { Aspirin with no history } \\
\text { of coronary, cerebral } \\
\text { or peripheral vascular } \\
\text { symptoms or occlusive } \\
\text { event }\end{array}$ & 9 & 14.29 & $\begin{array}{l}\text { Metformin with type } 2 \\
\text { diabetes with or without } \\
\text { metabolic syndrome }\end{array}$ & 10 & 16.70 \\
\hline $\begin{array}{c}\text { Long-term (i.e>1 } \\
\text { month), long-acting } \\
\text { benzodiazepines and } \\
\text { benzodiazepines with } \\
\text { long-acting metabolites }\end{array}$ & 7 & 11.1 & $\begin{array}{l}\text { Angiotensin Converting } \\
\text { Enzyme (ACE) inhibitor } \\
\text { with chronic heart failure }\end{array}$ & 4 & 6.67 \\
\hline $\begin{array}{l}\text { Digoxin at a long-term } \\
\text { dose }>125 \mathrm{mg} / \text { day with } \\
\text { impaired renal function }\end{array}$ & 4 & 6.35 & $\begin{array}{l}\text { ACE inhibitor following } \\
\text { acute myocardial } \\
\text { infarction }\end{array}$ & 4 & 6.67 \\
\hline
\end{tabular}

Table 4. The influence of gender, age, number of comorbidities and drugs on the occurrence of STOPP criteria.

\begin{tabular}{|c|c|c|c|c|c|c|}
\hline & & \multirow{2}{*}{ B } & \multirow{2}{*}{$p$} & \multirow{2}{*}{ OR } & \multicolumn{2}{|c|}{ 95\% CI. for OR } \\
\hline & & & & & Lower limit & Upper limit \\
\hline \multirow{5}{*}{ Model } & GENDER(FEMALE) & .040 & .926 & 1.041 & .448 & 2.417 \\
\hline & AGE (>75 years) & -.430 & .347 & .650 & .265 & 1.594 \\
\hline & $\begin{array}{c}\text { NUMBER OF } \\
\text { COMORBIDITIES }\end{array}$ & -.103 & .283 & .902 & .748 & 1.088 \\
\hline & NUMBER OF DRUGS & .202 & .027 & 1.223 & 1.023 & 1.463 \\
\hline & Constant & -1.006 & .111 & .366 & & \\
\hline
\end{tabular}

Table 5. The influence of gender, age, number of comorbidities and drugs on the occurrence of START criteria

\begin{tabular}{|c|c|c|c|c|c|c|}
\hline & & \multirow{2}{*}{ B } & \multirow{2}{*}{$p$} & \multirow{2}{*}{ OR } & \multicolumn{2}{|c|}{ 95\% CI. for OR } \\
\hline & & & & & Lower limit & Upper limit \\
\hline \multirow{5}{*}{ Model } & GENDER(FEMALE) & -.221 & .647 & .802 & .312 & 2.060 \\
\hline & AGE ( $>75$ years) & .462 & .344 & 1.587 & .610 & 4.131 \\
\hline & $\begin{array}{c}\text { NUMBER OF } \\
\text { COMORBIDITIES }\end{array}$ & .221 & .043 & 1.247 & 1.007 & 1.543 \\
\hline & NUMBER OF DRUGS & .177 & .067 & 1.194 & .988 & 1.443 \\
\hline & Constant & -3.460 & .000 & .031 & & \\
\hline
\end{tabular}


the number of drugs for the occurrence of STOPP criteria, in our research.

Our research has shown that the most commonly identified STOPP criteria are related to the use of benzodiazepines and to the presence of therapeutic duplication. Statins and metformin have been identified using the START criteria as potentially useful drugs which are missing in therapy. STOPP/START criteria for other drugs have been identified with considerably less significance or have not been identified. These results are in accordance with research conducted in Ireland on a large number of patients ${ }^{14,15}$. The total number of identified STOPP criteria per patient is slightly higher than in the Ryan et al sur$\mathrm{vey}^{14}$. Increased frequency and number of STOPP criteria observed in the group of our respondents can be partly explained by the lack of direct communication between prescribing physicians and pharmacists, as well as the lack of electronic patient documentation that would contain important data useful when prescribing new drugs.

The use of the STOPP criteria showed that in $22 \%$ of our patients is identified long-term use of benzodiazepines. The use of these drugs in elderly patients should be carried out in a shorter period of time and only when there are clear indications for their use. In about $17 \%$ of subjects, the presence of duplication therapy was demonstrated, which is much higher in comparison with the results of the Cahir et al $(5 \%)^{6}$. It was most commonly a combination of two drugs for the treatment of asthma from the group of anticholinergics or beta 2 receptor agonists, while in minority of cases there were two nitrate vasodilators. In $14 \%$ of patients the STOPP criteria were applied when identified the use of aspirin without history of coronary, cerebral or peripheral vascular symptoms or diseases.

The number of STOPP criteria registered in our previous research conducted in primary care patients in the city of Niš is in accordance with the obtained results of this study $(0.23 \pm 0.05 \text { versus } 0.20 \pm 0.15)^{16}$.

The frequency of fulfilled START criteria is consistent with the results of Ryan et $\mathrm{al}^{14}$. Previous research in our country showed a significantly higher representation of START criteria at the level of primary health care ${ }^{17}$.

The most commonly identified failures in prescribing drugs, using the START criteria are related to the cardiovascular and endocrine system. The absence of statins from prescribed therapy was observed in $19 \%$ of patients which is $31.70 \%$ of the total number of identified START criteria. The American College of Cardiology/American Heart Association (ACC/AHA) guidelines from 2018 define chronic kidney disease as a risk factor for the prevention of atherosclerotic cardiovascular disease and recommend the use of statins in these patients if they are not dialyzed. However, the results of individual studies show a higher incidence of adverse statin effects in reduced renal function, and each patient must be individually approached when considering these START criteria $^{18,19}$. In a significantly smaller number of patients, the absence of angiotensin converting enzyme inhibitors and metformin in therapy was observed. In $13 \%$ of patients, which is $21.70 \%$ out of the total applied START criteria, has been registered in endocrine system disorders. The criterion for the application of statins in patients with diabetes mellitus type 2 has been the presence of the main cardiovascular risk factors. A lack of metformin has been identified in patients with diabetes mellitus type 2 with or without the presence of metabolic syndrome $(10 \%)$. According to our results, the absence of aspirin prescribing has not been registered, opposite to the findings of other researchers ${ }^{20-22}$.

Statistical analyses were used to assess the influence of different factors on the occurrence of STOPP/ START criteria. Gender of patients, age categories (65-74 years and above 75 years), the number of drugs in therapy and the number of comorbidities were evaluated. The most significant impact on the occurrence of STOPP criteria has the number of drugs, while the number of comorbidities is singled out as the most important factor for the START criteria.

In the randomized controlled study of Gallagher et al it was reported that the application of STOPP/ START criteria with intervention proposed by a clinical pharmacist, as a member of a health care team, significantly improved the appropriateness of prescribing ${ }^{8}$. The assessment was performed by the Medication Appropriateness Index (35.7\% risk reduction) and the Assessment of Underutilization Index (21.0\% risk reduction). This improvement was sustained during the six-month period. The prevalence of failure of therapy and mortality was lower in the intervention group, but the differences were not statistically significant ${ }^{5}$. A survey involving the application of STOPP/START criteria in order to assess the impact on quality of life has not been recorded yet. Direct costs of PIP and benefits of pharmacists' interventions have been documented ${ }^{23}$. In our survey, the pharmacoeconomic study has not been conducted due to lack of economic data.

\section{Conclusions}

The health care of the elderly population is a challenge for healthcare providers as well as for patients, their caregivers and the entire health system. The presence of a relatively high percentage of 
inadequately prescribed drugs in the treatment of the elderly adults with different stages of renal failure has been registered in our research using STOPP and START criteria.

Application of STOPP and START criteria by pharmacist, associated with clinical findings provided by physician may reduce inappropriate use of polypharmacy, as well as avoid adverse effects of drugs. This approach offers numerous benefits to geriatric patients and improves everyday clinical practice.

The presence of potentially inadequate prescribing and the lack of potentially useful drugs in the complex pharmacotherapy of the elderly patients are the reasons for including pharmacists in a team which creates optimal pharmacotherapy for the elderly.

A pharmacist, as medication expert in interprofessional team, may have beneficial influence on health-related outcomes and pharmacoeconomic issues.

\section{Compliance with Ethics Requirements:}

"The authors declare no conflict of interest regarding this article"

„The authors declare that all the procedures and experiments of this study respect the ethical standards in the Helsinki Declaration of 1975, as revised in 2008(5), as well as the national law. Informed consent was obtained from all the patients included in the study"

"No funding for this study"

\section{References}

1. Pokrajac M. Farmakokinetika, 3th ed, Biograf, Beograd, 2007.

2. Yayla ME, Bilge U, Binen E, Keskin A. The use of START/ STOPP criteria for elderly patients in primary care. Scientific World Journal 2013;2013:165873.

3. O'Mahony D, O'Sullivan D, Byrne S, O'Connor MN, Ryan C, Gallagher P. STOPP/START criteria for potentially inappropriate prescribing in older people: version 2. Age Ageing 2015; 44(2): 213-218.

4. Vrdoljak D, Borovac JA. Medication in the elderly - considerations and therapy prescription guidelines. Acta Medica Academica 2015; 44(2): 159-168.

5. Hill-Taylor B, Sketris I, Hayden J, Byrne S, O'Sullivan D, Christie R. Application of the STOPP/START criteria: a systematic review of the prevalence of potentially inappropriate prescribing in older adults, and evidence of clinical, humanistic and economic impact. J Clin Pharm Ther 2013; 38(5): 360-372.

6. Cahir C, Fahey T, Teeling M, Teijeur C, Feely J, Bennett $\mathrm{K}$. Potentially inappropriate prescribing and cost outcomes for older people: a national population study. Br J Clin Pharmacol 2010; 69(5): 543-552.

7. O'Mahony D, Gallagher P, Ryan C, et al. STOPP \& START criteria: A new approach to detecting potentially inappropriate prescribing in old age. Eur Geriatr Med 2010; 1: 45-51.

8. Gallagher P, Ryan C, Byrne S, Kennedy J, O'Mahony D. STOPP (Screening Tool of Older Person's Prescriptions) and START (Screening Tool to Alert doctors to Right Treatment). Consensus validation. Int J Clin Pharmacol Ther 2008; 46(2): 72-83.

9. Manea M, Marcu D, Pantea Stoian A, et al. Heart failure with preserved ejection fraction and atrial fibrillation: a review. Rev Chim (Bucharest) 2018;69(11):4180-4184.

10. Diaconu CC. Statins and heart failure. Arch Balk Med Union 2019;54(3):219-221.

11. Diaconu C, Balaceanu A, Bartos D. Diuretics, first-line antihypertensive agents: are they always safe in the elderly? Romanian Journal of Internal Medicine 2014;52(2):87-90.

12. Hurmuz MZM, Janus SIM, van Manen JG. Changes in medicine prescription following a medication review in older high-risk patients with polypharmacy. Int J Clin Pharmacol Ther 2018; 40(2):480-487.

13. Passarelli MC, Jacob-Filho W, Figueras A. Adverse drug reactions in an elderly hospitalised population: inappropriate prescription is a leading cause. Drug Aging 2005; 22(9): $767-77$.

14. Ryan C, O'Mahony D, Kennedy J, Weedle P, Byrne S. Potentially inappropriate prescribing in an Irish elderly population in primary care. Br J Clin Pharmacol 2009; 68(6):936-947.

15. Gallagher P, O'Mahony D. STOPP (Screening Tool of Older Persons' potentially inappropriate Prescriptions): application to acutely ill elderly patients and comparison with Beer's criteria. Age Ageing 2008;37(6):673-679.

16. Catić-Đorđević A, Stefanović N, Veličković-Radovanović R. STOPP/START criteria for optimizing therapy in the geriatric population. Arh Farm 2018;68:218-219.

17. Ćulafić M, Murganić A, Trajković $\mathrm{H}$ et al. Assessment of potentially inappropriate medication prescribing using PIM Check-a. Arh Farm 2018;68:495-496.

18. Mefford MT, Rosenson RS, Deng L et al. Trends in statin use among US adults with chronic kidney disease, 1999-2014. J Am Heart Assoc 2019;8(2): e010640.

19. Zavidić T, Lodeta B, Lovrinić Đ. Use of statins in patients with chronic kidney disease for the prevention of cardiovascular disease. Acta Med Croatica 2016;70: 301-307.

20. Nedin Ranković G, Janković SM, Veličković Radovanović $\mathrm{R}$, et al. Potentially inappropriate prescribing of drugs in elderly patients on chronic hemodialysis treatment. Clinical Nephrology 2018;89(6):453-460.

21. Tiglis M, Neagu TP, Elfara M, et al. Nefopam and its role in modulating acute and chronic pain. Rev Chim (Bucharest) 2018;69(10):2877-2880.

22. Paraschiv B, Dediu G, Iancu A, Bratu O, Diaconu C. Superior vena cava syndrome - review. Arch Balk Med Union 2017;52(1):39-43.

23. Campins L, Serra-Prat M, Palomera E, Bolibar I, Martínez MA, Gallo P. Reduction of pharmaceutical expenditure by a drug appropriateness intervention in poly medicated elderly subjects in Catalonia (Spain). Gac Sanit 2019; 33(2):106-11. 